\title{
Evaluation of Arctic Land Snow Cover Characteristics, Surface Albedo, and Temperature during the Transition Seasons from Regional Climate Model Simulations and Satellite Data
}

\author{
X. Zhou, ${ }^{1}$ H. Matthes, ${ }^{1}$ A. Rinke, ${ }^{1}$ K. Klehmet, ${ }^{2}$ B. Heim, ${ }^{1}$ W. Dorn, ${ }^{1}$ D. Klaus, ${ }^{1}$ \\ K. Dethloff, ${ }^{1}$ and B. Rockel ${ }^{2}$ \\ ${ }^{1}$ Alfred Wegener Institute, Helmholtz Centre for Polar and Marine Research, Telegrafenberg A45, 14473 Potsdam, Germany \\ ${ }^{2}$ Institute of Coastal Research, Helmholtz-Zentrum Geesthacht, Max-Planck-Straße 1, 21502 Geesthacht, Germany \\ Correspondence should be addressed to X. Zhou; lion12580@gmail.com
}

Received 24 April 2014; Accepted 10 August 2014; Published 18 September 2014

Academic Editor: Yijun He

Copyright (@) $2014 \mathrm{X}$. Zhou et al. This is an open access article distributed under the Creative Commons Attribution License, which permits unrestricted use, distribution, and reproduction in any medium, provided the original work is properly cited.

\begin{abstract}
This paper evaluates the simulated Arctic land snow cover duration, snow water equivalent, snow cover fraction, surface albedo, and land surface temperature in the regional climate model HIRHAM5 during 2008-2010, compared with various satellite and reanalysis data and one further regional climate model (COSMO-CLM). HIRHAM5 shows a general agreement in the spatial patterns and annual course of these variables, although distinct biases for specific regions and months are obvious. The most prominent biases occur for east Siberian deciduous forest albedo, which is overestimated in the simulation for snow covered conditions in spring. This may be caused by the simplified albedo parameterization (e.g., nonconsideration of different forest types and neglecting the effect of fallen leaves and branches on snow for deciduous tree forest). The land surface temperature biases mirror the albedo biases in their spatial and temporal structures. The snow cover fraction and albedo biases can explain the simulated land surface temperature bias of ca. $-3^{\circ} \mathrm{C}$ over the Siberian forest area in spring.
\end{abstract}

\section{Introduction}

The Arctic belongs to the key regions in the global climate system, evidenced by many rapid environmental changes (e.g., $[1,2])$. In this context, the land surface temperature (LST) is an important variable, because it reflects the changes in the surface energy budget, the energy exchange between land and atmosphere and feedbacks with cryospheric variables like snow cover and frozen ground.

In addition to vegetation and soil moisture, the snow cover characteristics have a significant impact on the LST (e.g., $[3,4])$. The isolating snow effect leads to less cooling of the ground under snow and reduced upward longwave radiative fluxes and thus to increased cooling of snow surface. But most important is the snow-albedo feedback mechanism (e.g., $[5,6])$, at least when solar irradiation is present. Overall, the occurrence of a snow pack manifests in modified sensible and latent surface heat fluxes.
The processes in spring and autumn are particularly crucial here. During the transition seasons fast changes of LST occur, whereby the timing of seasonal warming/cooling is related to the onset of snow melt/snow fall. A warming climate is discussed to move the onset of snowmelt and reduce the overall snow cover duration (SCD) [7]. The observed decrease in snow cover duration over the Arctic is largely caused by earlier onset of snow melt in spring [8], which has a direct impact on air and ground temperatures. When melting occurs, the snow cover acts as a heat sink because of the large amounts of energy required for phase change.

The snow cover characteristics, namely, snow depth (or snow water equivalent, SWE) and snow cover fraction (SCF), but also SCD and other characteristics, show distinct regional heterogeneities. Regional climate models (RCMs) are suitable tools for simulating these snow characteristics and associated land surface conditions at relatively high horizontal 
resolution. The studies of Shkolnik et al. [9] and Klehmet et al. [10] demonstrated a reasonable agreement of RCM simulated Siberian snow characteristics compared against different reanalysis and satellite data. Further, Klehmet et al. [10] assessed the added value of their SWE simulations compared to reanalysis data.

In the present study, we evaluate the simulated LSTs of the RCM HIRHAM5 against ERA-Interim reanalysis data with respect to the following questions: is the model able to reproduce observed LSTs? Can biases in the modeled LST be explained with biases in snow cover characteristics? Does the influence of albedo on LST play a key role? To answer these questions, we analyze the observed and modeled three snow cover characteristics (SWE, SCF, and SCD). An accurate simulation of SWE is crucial in terms of hydrological processes, while SCF and SCD are important for the surface energy budget via the albedo. Thus, the simulated surface albedo and LST are simultaneously evaluated.

Different RCMs apply land surface models of quite different complexities. To present a first glimpse about the range of snow, surface albedo and temperature simulations over Siberia, some of the HIRHAM5 results have been compared with simulations from another RCM, namely, the COSMOCLM (CCLM), which has been applied over a Siberian subdomain recently [10].

\section{Observational and Modeled Data}

To evaluate monthly results from HIRHAM5 simulations, the following reference datasets have been used: (1) reanalysesderived snow water equivalent (SWE) from Canadian Meteorological Centre (CMC), ERA-interim and satellite-derived products from GlobSnow; (2) satellite-derived snow cover fraction (SCF) from MODIS and GlobSnow; (3) satellitederived surface albedo from MODIS and reanalyses data from ERA-interim; (4) land surface temperature (LST) from ERA-interim. A description of these datasets and of the employed model is given in the following.

\subsection{MODIS Satellite-Derived Data. The Moderate Resolution} Imaging Spectroradiometer (MODIS; http://modis.gsfc.nasa .gov/index.php) is a passive optical and thermal sensor system aboard the Terra and Aqua satellites. The MODIS satellites provide global daily coverage. The wider range of data products derived from MODIS observations are valuable for evaluating the spatial-temporal results from model simulations.

2.1.1. MODIS Surface Albedo. The albedo data used here is the Climate Modeling Grid (CMG) Nadir Bidirectional Reflectance Distribution Function (BRDF) Adjusted Reflectance (NBAR) Product "MODIS/Terra Nadir BRDFAdjusted Reflectance 16-Day L3 Global 0.05Deg CMG”, which is derived from white-sky albedo only. Since the white-sky albedo represents the integration over all zenith angles, the error of the high quality MODIS operational albedos at $500 \mathrm{~m}$ is well less than $5 \%$ at the majority of the validation sites studied thus far, and even those albedo values with low quality flags have been found to be primarily within $10 \%$ of the field data (e.g., [11-13]). Note that along coastlines, the $1 \mathrm{~km}$ pixels that lie over shallow water are averaged into the 0.05 degree CMG pixels, which may cause biases for these areas. The albedo data are downloaded from http://modis-atmos.gsfc .nasa.gov/ALBEDO/. The data are available for every 8 days as 16-day running mean, and we interpolated the corresponding time intervals to obtain monthly means.

2.1.2. MODIS Snow Cover Fraction (SCF). The "MODIS/ Terra Snow Cover Monthly L3 Global 0.05Deg CMG, Version 5 " data used in this study was obtained from the National Snow and Ice Data Center in Boulder, Colorado, USA ([14]; http://nsidc.org/data/mod $10 \mathrm{~cm} . h t m l)$. The reason why we selected the Terra data as a primary key for snow detection is the characteristic of snow to have high visible reflectance and low reflectance in the near infrared, MODIS band $6(1.6 \mu \mathrm{m})$, which is fully functional in Terra but only $30 \%$ functional in Aqua. SCF is calculated by using the regression equation of Salomonson and Appel [15], which is based on the Normalized Difference Snow Index (NDSI) values of each observing pixel. For more detailed information we refer to the MODIS snow products user guide [16]. The monthly snow product was derived from the daily 0.05 degree resolution product. It has an overall absolute accuracy of about 93\%, but with remaining problems caused by snow/cloud discrimination [17]. Arsenault et al. [18] evaluated this product with in-situ measurements collected in Colorado and Washington states and identify a total SCF bias of about $7-17 \%$. A similar study from Simic et al. [19] over the Canadian evergreen forests concludes a total error of about $10-20 \%$.

2.2. CMC Snow Water Equivalent (SWE). The operational analysis of snow depth data at the Canadian Meteorological Centre (CMC) is a suitable dataset for evaluating model simulations [20]. These $24 \mathrm{~km}$ horizontal resolution and daily datasets have been downloaded from http://nsidc.org/data/ docs/daac/nsidc0447_CMC_snow_depth/. The analysis is based on station observations and a background snow depth field, which is generated by a simple snowpack model forced with European Centre for Medium-Range Weather Forecasts (ECMWF) precipitation and $2 \mathrm{~m}$ air temperature [20]. Thus, the analysis makes use of precipitation forecasts and an analysis of screen level temperature to estimate snowfall and snowmelt. Wherever snow depth observations are available, these are incorporated using the method of statistical interpolation, performed every six hours on a $1 / 3^{\circ}$ grid. For details we refer to Brasnett [21]. In regions with relatively good station coverage the dataset is fairly reliable, while it is considered as reasonable estimate of snow depth over data-poor Arctic regions [22]. CMC derived the monthly SWE data from the snow depth using a lookup table of snow density, which is in turn based on snow course observations [23]. However, we assumed a constant snow density of $330 \mathrm{~kg} / \mathrm{m}^{3}$ to be consistent with the approach that is used in the HIRHAM5 model (see Section 2.5). 
2.3. GlobSnow Data. GlobSnow is a satellite-derived snow products produced within the GlobSnow funded by the European Space Agency (ESA) [24]. The SCF and SWE data are based on the aggregation of optical satellites for SCF and microwave satellites for SWE passing over within a calendar month, weather station observations of snow depth, and forward simulations employing a semi-empirical snow emission model. The $25 \mathrm{~km}$ resolution data have been downloaded from http://www.globsnow.info/. This most recent monthly L3B-product (v2.0) has major improvements over the heterogeneous landscapes and in regions with significant lake coverage $[25,26]$. Concerning SWE retrieval accuracy, improvements are reported over Tundra and Northern Boreal forests [26]. The GlobSnow dataset contains satelliteretrieved information on snow extent, SCF, and SWE. The mapping of SCF is solved from a semiempirical model based on reflectance observation [27]. A root-mean-square error (RMSE) of $15 \%$ was calculated for the area of drainage basins when validating the snow cover with snow course observations [27]. Salminen et al. [28] find an average error of about $5-7 \%$ for boreal forest. The SWE data has been derived using the fuzzy mutual information (FMI) algorithm [29] in combination with a time-series melt-detection algorithm [8] that is based on passive microwave radiometer data and synoptic station data, which leads to poorer performance in mountain areas than non-mountain areas [30] due to strong orographic complexity. Wet snow also contributes to the difficulties in the retrieval algorithm [30]. Additionally, vegetation cover affects the accuracy of the data so that dense forest will for example, result in an underestimation of SWE [31]. Takala et al. [30] compared GlobSnow SWE with station data from the former Soviet Union, Finland, and Canada. The authors found that the RMSE is less than $40 \mathrm{~mm}$ in cases of SWE smaller than $150 \mathrm{~mm}$, while the bias increases if SWE is larger than $150 \mathrm{~mm}$. Even though, GlobSnow better represents the large-scale SWE pattern in comparison with MODIS, because its SWE product combines satellitebased passive microwave measurements with ground-based observations [30].

2.4. ERA-Interim Data. ERA-interim represents the ECMWF's new generation global reanalysis [32] that is based on the Integrated Forecasting System (IFS) model. This reanalysis incorporates many important IFS improvements such as an increased model resolution, improved model physics, the use of four-dimensional variational (4D-Var) assimilation, and various other changes in the analysis methodology [33]. ERA-interim reanalysis data have a horizontal resolution of T255 (ca. $0.75^{\circ}$ ). Snow depth and SWE are first estimated by the forecast model based on Douville et al. [34] and then updated based on a Cressman analysis of station observations of snow depth and (when available) SCF by satellite data [35]. There are two reasons why the derived snow data are limited [32]: First, the surface data assimilation system uses a relatively simple data interpolation scheme and does not generate comprehensive information about data quality control and usage. Second, the incorrect introduction of geolocation during the processing of the Interactive Multisensor Snow and Ice Mapping System (IMS) product at ECMWF introduces biases. In the ECMWF forecast model, the SCF $f_{\text {sn }}$ is linearly related to the SWE $S$ in meters [36]:

$$
f_{\mathrm{sn}}=\min \left[1, \frac{S}{S_{c}}\right],
$$

where $S_{c}=0.015 \mathrm{~m}$ is the threshold of snow thickness in $\mathrm{m}$ water equivalent, above which the grid cell is fully covered with snow. Then the snow mass budget can be written as

$$
\rho \frac{\partial S}{\partial t}=F+f_{\mathrm{sn}}\left(E_{\mathrm{sn}}-M_{\mathrm{sn}}\right)
$$

where $\rho$ is snow density, $F$ is the snow fall, and $E_{\text {sn }}$ and $M_{\text {sn }}$ are snow sublimation and melting. Snow albedo for forestfree areas is time dependent and parameterized according to the formulation of Verseghy [37] and Douville et al. [34]. The snow albedo is separately calculated for melting conditions:

$$
\alpha_{\mathrm{sn}}^{t+1}=\alpha_{\mathrm{sn}}^{t}-\frac{\varepsilon_{a} \Delta t}{T_{0}}
$$

and nonmelting conditions:

$$
\alpha_{\mathrm{sn}}^{t+1}=\left(\alpha_{\mathrm{sn}}^{t}-\alpha_{\min }\right) \exp \left(\frac{-\varepsilon_{f} \Delta t}{T_{0}}\right)+\alpha_{\min } .
$$

Here, $\varepsilon_{a}=0.008$ and $\varepsilon_{f}=0.24$ are constants to control albedo changes and snow melting, respectively, $\alpha_{\min }=0.5$ represents the minimum snow albedo, and $T_{0}=86400 \mathrm{~s}$ is the length of a day in seconds. If snow fall is larger than $1 \mathrm{kgm}^{-2} \mathrm{~h}^{-1}$, the snow albedo is reset to its assumed maximum value of $\alpha_{\max }=0.85$. For boreal forest-covered grid cells, the snow albedo is restricted to a maximum value of 0.2 . Finally, each grid cell albedo value is a linear relation of forest and nonforest areas. For full details we refer to Viterbo and Betts [38].

2.5. HIRHAM5 Model. HIRHAM5 is an atmospheric RCM that combines the dynamical model core of HIRLAM [39] and the physical parameterizations of ECHAM5 [40]. The previous HIRHAM4 version has been applied to a wide range of Arctic climate studies (e.g., [41, 42]). Its circum-Arctic integration domain is shown in Figure 1 and has $218 \times 200$ grid points at a horizontal resolution of $0.25^{\circ}$ (about $25 \mathrm{~km}$ ). There are 40 vertical model levels in the atmosphere, ranging from approximately $10 \mathrm{~m}$ above the surface up to a height of $10 \mathrm{hPa}$. A Simulation for this domain, driven by ERA-Interim data, has been carried out for the time period of 2008-2010. LST is calculated solving the energy balance equation at the surface, thus linking atmospheric, surface and soil processes. According to Roeckner et al. [40] the energy balance equation is used in the form:

$$
C_{L} \frac{\partial T_{s}}{\partial t}=R_{\text {net }}+L E+H+G
$$

where $C_{L}$ is the heat capacity of the surface layer, $L E$ is the latent surface heat flux, $H$ is the sensible surface heat flux, $G$ is the ground heat flux, and $R_{\text {net }}$ is the net surface radiation. 


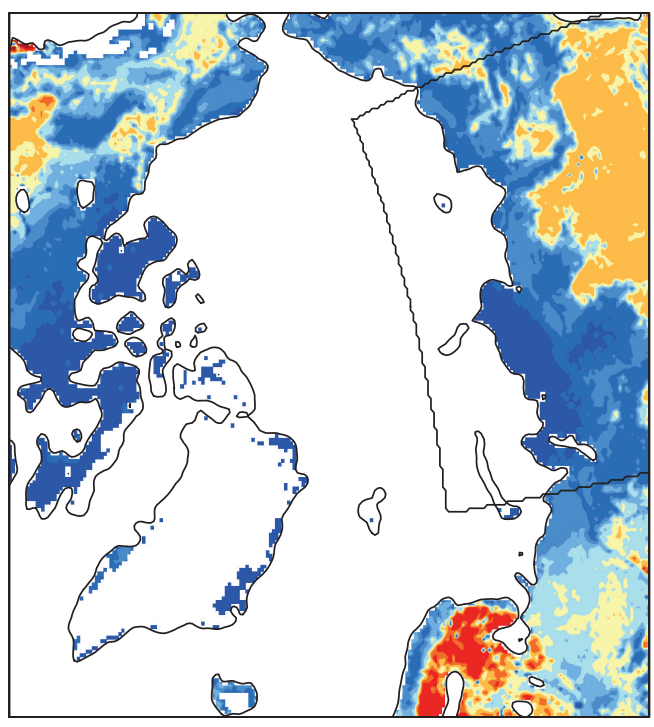

(a)

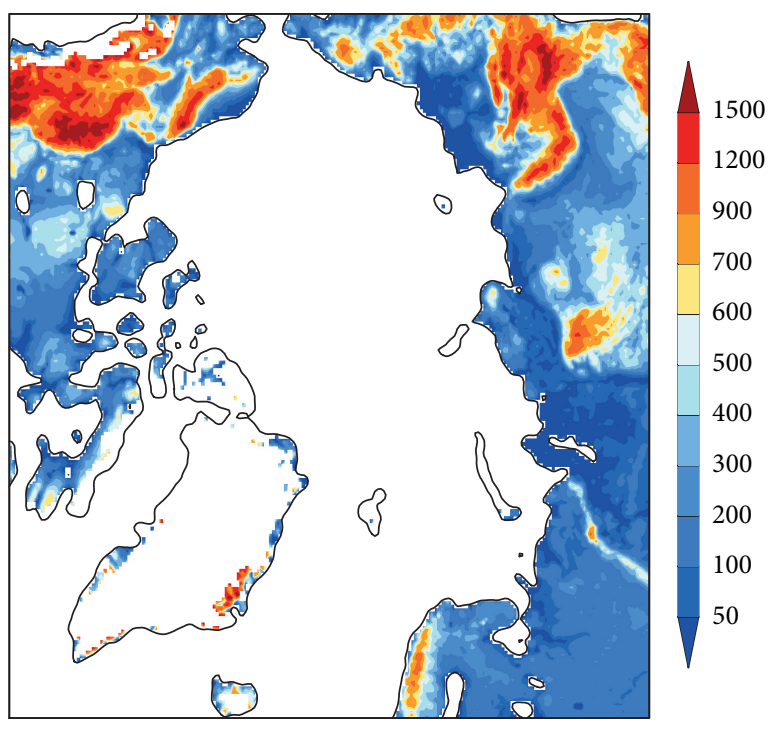

(b)

FIGURE 1: HIRHAM5 integration domain (ocean and glacier are excluded) and applied (a) forest fraction (\%) and (b) orography (m). The black window in (a) indicate the Siberian subdomain.

SWE is estimated by a budget equation that considers sublimation and deposition, snow fall, and snow melting. On the basis of SWE, the model derives snow cover fraction (SCF) as a function of forest fraction, interception capacity of the canopy, and slope of the terrain given by the subgrid-scale standard deviation of orography. SCF of a grid cell is given as

$$
f_{\text {sn }_{-} g}=f_{\text {for }} f_{\text {snc }}+\left(1-f_{\text {for }}\right) f_{\text {sn }},
$$

where $f_{\text {for }}$ is the forest fraction of the grid cell, $f_{\text {snc }}$ is the SCF on the canopy, and $f_{\text {sn }}$ refers to the SCF of bare ground.

The surface albedo of the land-covered part of a grid cell is calculated by modifying a background albedo field according to the calculated SCF. The background albedo is derived from satellite data allocated to a high-resolution map of major ecosystem complexes [43]. Over snow-covered land, the grid mean albedo depends on a number of parameters such as the fractional forest area, the leaf area index, the bare-soil albedo, the snow albedo, and SCF of both the ground and the canopy [44]. Similar to SCF, the surface albedo is derived as

$$
\alpha_{\text {surf }}=f_{\text {for }} \alpha_{\text {for }}+\left(1-f_{\text {for }}\right) \alpha_{g},
$$

where $\alpha_{\text {for }}$ is the albedo of forest, which depends on the leaf area index, snow on canopy and canopy albedo as well as bare soil albedo, while $\alpha_{g}$ is the ground albedo that depends on the bare soil and snow albedo as well as SCF of the ground.

2.6. CCLM Model. COSMO-CLM (CCLM, http://www.clmcommunity.eu/, [45]) is a nonhydrostatic atmospheric RCM that is based on the numerical weather prediction model Consortium for Small-scale Modeling (COSMO) performed in a Climate Limited-area Modelling (CLM). Recently, it has been applied for climate studies over Siberia [10]. The Siberian domain extends from the Laptev and Kara Seas to
Northern Mongolia and from the West Siberian Lowland to the border of the Sea of Okhotsk. The overlapping area with the HIRHAM5 domain is indicated by the black lines in Figure 1. A hindcast simulation has been conducted over the Siberian domain with $50 \mathrm{~km}$ horizontal resolution for the period 2008-2010 using ERA-interim forcing data.

For the consideration of snow, a multilayer snow model within the land-surface scheme TERRA-ML is used. The multilayer snow model is introduced in a preliminary version by the Deutscher Wetterdienst. In the performed simulation, two snow layers have been chosen as more layers did not improve the results in the current setup. Each layer is described separately by temperature, water content, and porosity, according to the snow density. Further information concerning the multilayer snow model is given in Klehmet et al. [10]. SCF is calculated in CCLM using the following formula:

$$
f_{\text {sn }}=\operatorname{Max}\left[0.01 ; \min \left(1.0 ; \frac{\mathrm{SWE}}{\delta_{s}}\right)\right] \text {, }
$$

where $\delta_{s}=0.015 \mathrm{~m}$ for snow [46].

The surface albedo over land is a mean of bare soil albedo, vegetation albedo and snow albedo if snow is present. In the used CCLM version, soil albedo is a function of soiltype and soil water content in the top soil layer. TERRAML distinguishes between seven soil types based on the Digital Soil Map of the World (http://www.fao.org/home/en/). Vegetation is not explicitly included. Rather an external dataset of land cover is used and specific plant characteristics are derived from the dominant land cover and land use type. These characteristics are fractional area covered by plants (plant cover), leaf area index, and roughness length. Deciduous or evergreen forest is considered separately to 
better account for the influence on the snow albedo of forests. The snow albedo of forests $\alpha_{\text {sn_for }}$ is given by

$$
\begin{aligned}
\alpha_{\text {sn_for }}= & \alpha_{\text {sn }}\left(1-f_{\text {for }_{e}}-f_{\text {for }_{\mathrm{d}}}\right) \\
& +\alpha_{\text {sn }_{\mathrm{e}}} f_{\text {for }_{\mathrm{e}}}+\alpha_{\mathrm{sn}_{\mathrm{d}}} f_{\text {for }_{\mathrm{d}}},
\end{aligned}
$$

where $\alpha_{\mathrm{sn}}$ is the snow albedo on bare soil, $f_{\text {for }}$ and $f_{\text {for }}$ are the forest fractions of evergreen or deciduous forest, and $\alpha_{\mathrm{sn}_{\mathrm{e}}}$ and $\alpha_{\mathrm{sn}_{\mathrm{d}}}$ the snow albedo of both forest types.

In addition, a time-dependent snow albedo is included by using an ageing condition. A detailed description of CCLM is presented by [46].

\section{Analysis Methods}

All the gridded observational data have been interpolated onto the HIRHAM5 grid. This allows us to compare the datasets to one another and to evaluate the HIRHAM5 simulation by reference to these various observations. Further, monthly area-averages over a Siberian domain (see Section 2.6) have been calculated for all the datasets.

According to the simulation period, the paper discusses monthly and seasonal (spring-MAM, autumn-SON) SWE, snow cover duration (SCD), SCF, albedo, and LST averages over 2008-2010. On the one hand, we present the spatial maps for spring and autumn and on the other hand, we discuss the annual cycle of the variables averaged over the Siberian domain.

As an additional measure for snow evaluation we calculated the SCD from daily CMC data and the HIRHAM5 model. Discussing SCD on a seasonal scale allows a simplified approach on analyzing earlier onset of snow melt or later onset of snow fall, as these occur in the transition seasons. Spring SCD counts the number of days for each grid cell during the period from March 1st to May 31st for which the cell was snow-covered. Analogous, autumn SCD considers the period from September 1st to November 30th. In accordance with other studies (e.g., [47-49]), a threshold of daily $2 \mathrm{~cm}$ SWE was applied to decide if the grid cell is snow-covered or not. Thus, spring SCD characterizes the snow free start, while autumn SCD characterizes the timing of snow accumulation onset after summer and before permanent snow cover occurs.

Snow cover and depth, albedo, and LST are highly dependent on land cover or vegetation type. Therefore, we also separately discuss them with respect to forest and nonforest grid cells. Based on a global $1 \mathrm{~km}$-resolution dataset from Hagemann [43], a threshold of 50\% forest fraction has been applied according to Figure 1.

\section{Results and Discussion}

\subsection{Snow Cover and Albedo}

\subsubsection{Spatial Patterns in Circum-Arctic Domain}

Snow Cover Duration (SCD). The spatial patterns of spring and autumn SCD are shown in Figure 2. The spring patterns show a strong zonally symmetric structure, but orographically influenced, as SCD is largely affected by surface temperature during the snow melt period. The shortest SCD is found over lower latitudes (e.g., over Northern Europe and west Russia); it ranges there from 10 days to 60 days. The longest SCD of more than 70 days occurs over the West Siberian Plains, the Taymir Peninsula, and the Canadian archipelago and in mountain areas. The timing of snow cover onset in autumn is temperature and precipitation driven. Therefore, the autumn SCD spatial patterns are more regionalized than those in spring. Largest SCD of more than 60 days occur here over the mountainous regions which experience very early snow fall.

Generally, the simulated spatial SCD patterns agree with those from $\mathrm{CMC}$, but biases in absolute numbers occur. In spring, the model underestimates SCD of up to 25 days. Thus, the model shows the largest underestimation of up to $40 \%$ in the sub-Arctic areas. Smallest differences (of up to -4 days) are over the regions with the largest SCD (Taymir Peninsula, Lena river basin area, and Canadian archipelago). The largest underestimation of SCD in sub-Arctic areas in spring is caused by an underestimated snow amount, which might be related to an insufficient cyclone transported moisture and the localization of precipitation amount [10]. The general underestimation of SCD is further associated with biased melting onset and melting rate, which could be caused by the simplified snow parameterizations (such as the one-layer snow model or nonconsideration of snow aging) in HIRHAM5. In autumn, the model under- and overestimates (depending on the region) the SCD compared to CMC. The differences are of small-scale and manifested over mountainous regions, where the model tends to show higher SCD compared to CMC. The reasons could be, on the one hand, the higher model resolution and associated higher precipitation and snow depth and, on the other hand, the lower station density in CMC.

Snow Water Equivalent (SWE). The simulated spatial patterns of SWE are comparable with those from CMC but show some disagreement with GlobSnow and ERA-interim (Figures 3 and 4). Largest CMC-derived amount of SWE occur over the West Siberia plains and the Rocky Mountains, with SWE of more than $18 \mathrm{~cm}$ in spring and more than $4 \mathrm{~cm}$ in autumn. The model tends to overestimate the SWE in those regions by ca. $20-30 \%$ compared to CMC. The model biases compared to GlobSnow and ERA-interim are larger than CMC. GlobSnow shows the same large differences relative to CMC. Particularly, GlobSnow does not show a large amount of SWE over Alaska, the Canadian archipelago and the mountain areas. The differences between GlobSnow and $\mathrm{CMC}$ can reach more than $8 \mathrm{~cm}$. This may be due to the sparse measurements and the simplicity of the retrieval algorithm in GlobSnow (the algorithm is designed particularly for boreal forest; [50]).

Snow Cover Fraction (SCF). Spring and autumn SCF spatial patterns are shown in Figures 5 and 6. For autumn, GlobSnow has only been averaged over September and October due 

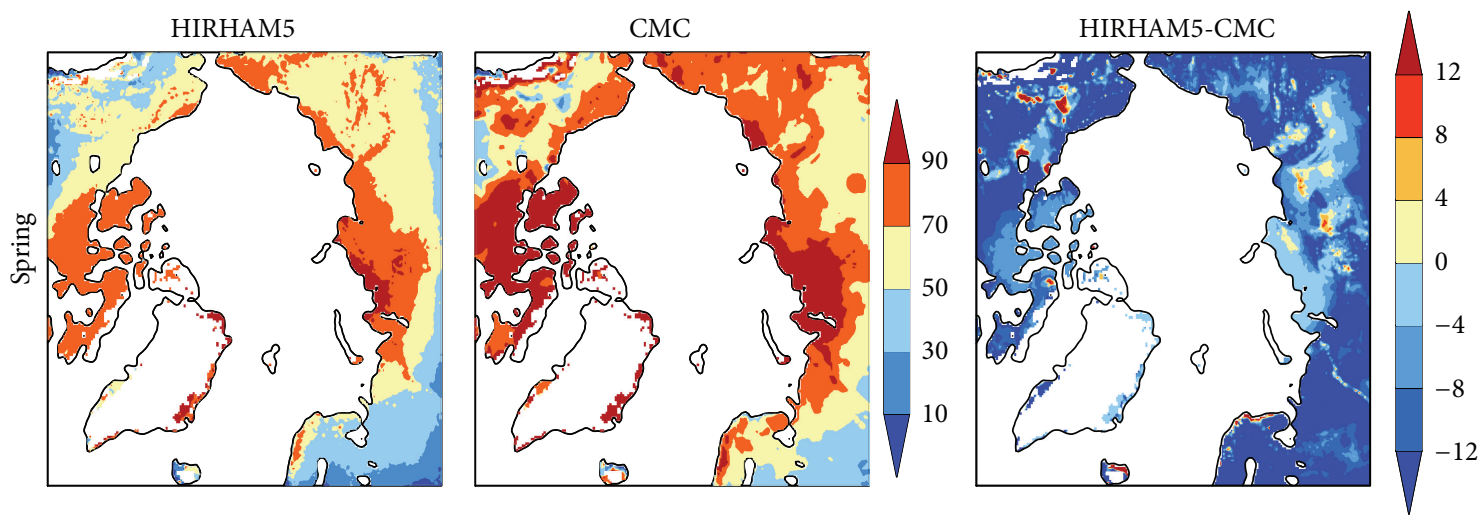

(a)
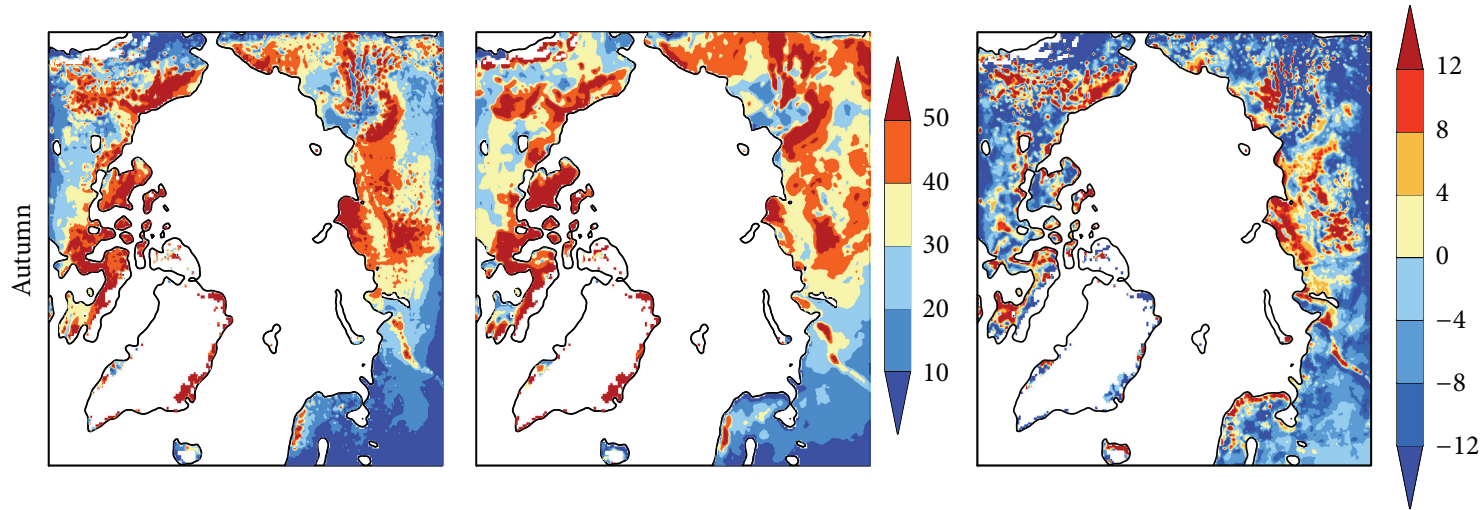

(b)

FIGURE 2: Snow cover duration (days) averaged over 2008-2010 for spring (a) and autumn (b) derived from HIRHAM5, CMC and their difference "HIRHAM5 minus CMC".

to lack of optical satellite acquisitions which is caused by reduced incoming and reflected radiation at high latitudes.

In spring, clear zonally symmetric and orographydependent structures appear, similarly to those seen in SCD. The largest snow cover in HIRHAM5 is found over the west Siberian plains and the Taymir Peninsula, the Kolyma River basin, and the Canadian archipelago. SCF reaches there up to more than 0.7. Other regions (e.g., Lena river basin, Northern Europe, and Alaska) show smaller SCF of 0.30.6. MODIS and GlobSnow SCF spring patterns are in good agreement to each other. Both show high values of SCF of 0.7-0.9 over the whole Arctic. Compared with MODIS, HIRHAM5 calculates generally similar spatial patterns but much smaller amplitudes of SCF within the whole domain in both seasons. The regionally dependent bias ranges between -0.4 and -0.1 . The modeled spatial SCF patterns follow closely those of SWE because SCF is derived from SWE (see Section 2.5). Compared with GlobSnow, the HIRHAM5 biases are quite similar with the comparison against MODIS in both seasons. However in autumn, the HIRHAM5 bias compared to GlobSnow shows smaller scale biases of higher amplitude. This is caused by the lack of GlobSnow data due to reduced incoming and reflected radiation at high latitudes in this season.
Surface Albedo. The simulated surface albedo shows biases in spring and autumn, compared to both ERA-interim and MODIS (Figure 7). In spring, both "HIRHAM5 minus ERAinterim" and "HIRHAM5 minus MODIS" show a main feature: HIRHAM5 has a positive albedo bias compared to both datasets (of up to 0.4 compared with ERA-interim and of up to 0.3 compared with MODIS) over the areas where the forest cover fraction is relatively large (see Figure 1) and forest is mainly comprised of deciduous trees, that is, over the West Russian Arctic, Lena River basin, and parts of river basins in Alaska and Canada. In autumn, a similar spatial bias pattern is obvious in comparison with ERA-interim, while the bias in comparison with MODIS is largely latitude dependent. The results indicate that HIRHAM5 overestimates the surface albedo in these forest areas for both seasons. It is worth noting that this does not happen in the Scandinavia area where forest cover fraction is even higher, because the forest type is different: deciduous tree versus evergreen tree. Also there is no snow cover in Scandinavia during spring months despite being at high altitudes. Fallen leaves and branches on snow coverage, which are not considered in the albedo parameterization, would cause a much darker albedo despite snow coverage. This could be responsible for the positive bias over the Siberian region. This result is in agreement with Roesch and Roeckner [51], even though HIRHAM5 shows shorter 

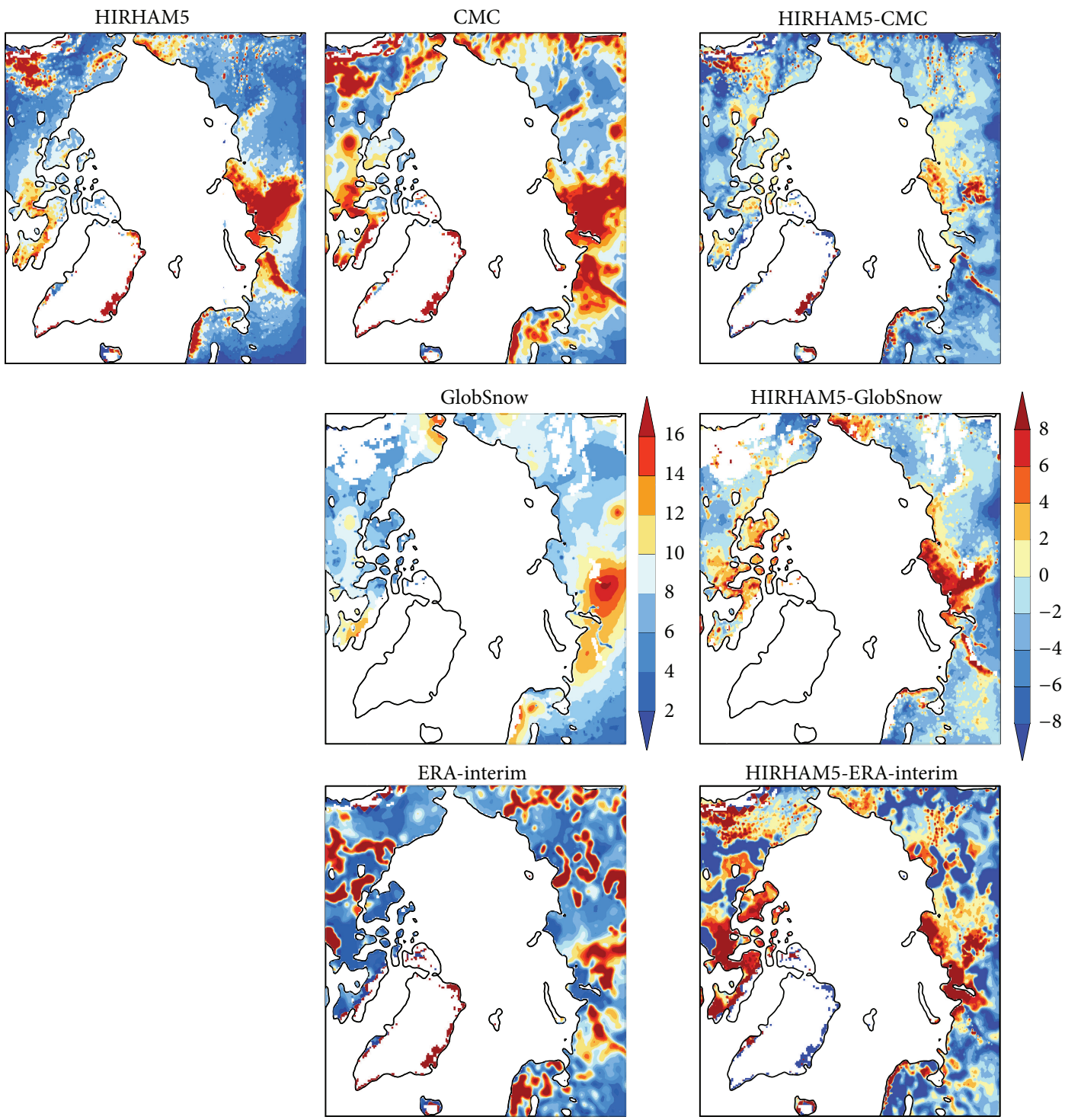

HIRHAM5-ERA-interim

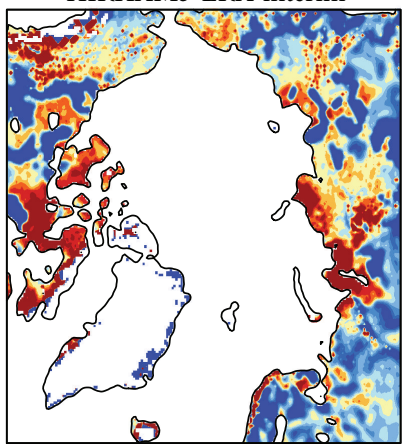

FIGURE 3: Snow water equivalent $(\mathrm{cm})$ averaged over 2008-2010 for spring derived from HIRHAM5, CMC, GlobSnow, ERA-Interim and their corresponding differences "HIRHAM5 minus CMC", "HIRHAM5 minus GlobSnow", "HIRHAM5 minus ERA-Interim".

spring SCD and underestimated SCF. Further, in spring, there are relatively large differences between the two biases "HIRHAM5 minus ERA-interim" and "HIRHAM5 minus MODIS" in specific areas like the Canadian archipelago and the Kola Peninsula. There HIRHAM5 shows large negative albedo biases (of up to -0.3) with respect to MODIS, but only small negative or even positive biases compared to ERAinterim. In autumn, large positive albedo biases (compared to MODIS) are located over the West Siberia Plain, the Taymir Peninsula, and the Canadian archipelago, which may come from the longer autumn SCD (Figure 2). Biases with respect to ERA-interim derived albedo are a result of the different parameterizations compared to HIRHAM5. As for MODIS-derived albedo, cloud cover affection is one important limitation. On the one hand, satellite observation is not continuous due to cloud cover; on the other hand, when there is snow cover, optical satellite products may contain undetected and unmasked cloud cover for snow and ice land surface [52].

4.1.2. Annual Cycle over the Siberian Subdomain. As shown, snow cover and albedo are influenced by the vegetation cover. Therefore, their annual cycle has been analyzed separately for forest and nonforest regions. To enable a comparison with CCLM simulations (see Section 2.6), the evaluation is restricted here to the Siberian subdomain (see Figure 1). Due to the difference of forest fraction between HIRHAM5 and CCLM, we consider the forest cover fraction between 0.5-1.0 in both model as forest area and forest cover fraction between $0-0.5$ in both model as nonforest area.

Snow Water Equivalent (SWE). Figure 8 shows significant differences in the annual cycle of SWE, particularly for forest areas. Over forest, the observational datasets ERA-interim, 

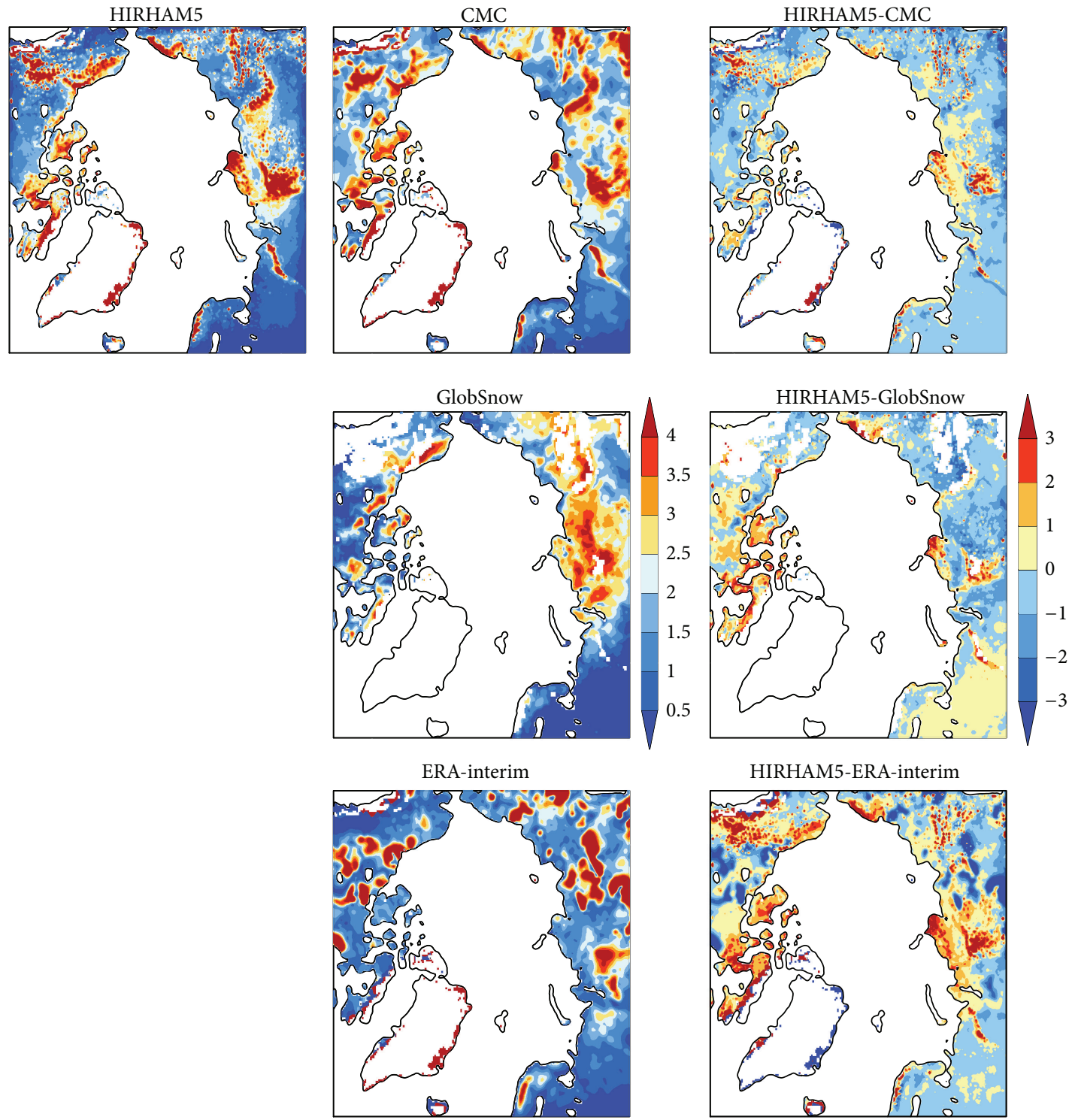

FIGURE 4: Snow water equivalent $(\mathrm{cm})$ averaged over 2008-2010 for autumn derived from HIRHAM5, CMC, GlobSnow, ERA-Interim and their corresponding differences "HIRHAM5 minus CMC", "HIRHAM5 minus GlobSnow", "HIRHAM5 minus ERA-Interim".

CMC, and GlobSnow show differences from November to May. While CMC and GlobSnow largely agree, ERA-interim shows systematically higher SWE by ca. $5 \mathrm{~cm}$. For nonforest areas, the observational data are closer to each other, but GlobSnow shows smaller SWE compared to CMC and ERAinterim data from February to April.

For both regions, HIRHAM5 tends to underestimate SWE, but particularly in forest areas. The underestimation of SWE in the forest region is also presented by CCLM, but mainly during the winter months. Except for May, both models are better in reproducing SWE over nonforest areas than over forest areas. This may be caused by the complexity of forest vegetation.

Snow Cover Fraction (SCF). Figure 9 shows that for both forest and nonforest areas, MODIS and GlobSnow-derived SCF agree well in spring (March-May), but differ significantly in autumn (October-November). A systematic underestimation of HIRHAM5-simulated SCF especially in spring has already been discussed (see Section 4.1.1; Figures 5 and 6), although the model calculation of SCF considers various surface properties (e.g., orography, surface type, and vegetation cover). Over both areas, forest and nonforest areas, HIRHAM5 strongly underestimates SCF by $0.2-0.5$ in April and May compared to both MODIS and GlobSnow. In autumn, the models agreement with the observations is better, particularly with GlobSnow. Compared to MODIS, the model again shows an underestimated SCF. In October and November, HIRHAM5 agrees with GlobSnow, while MODIS shows higher SCF especially for nonforest areas. Takala et al. [30] argue that GlobSnow is of better quality than MODIS in the Russian area. Compared with HIRHAM, CCLM shows 

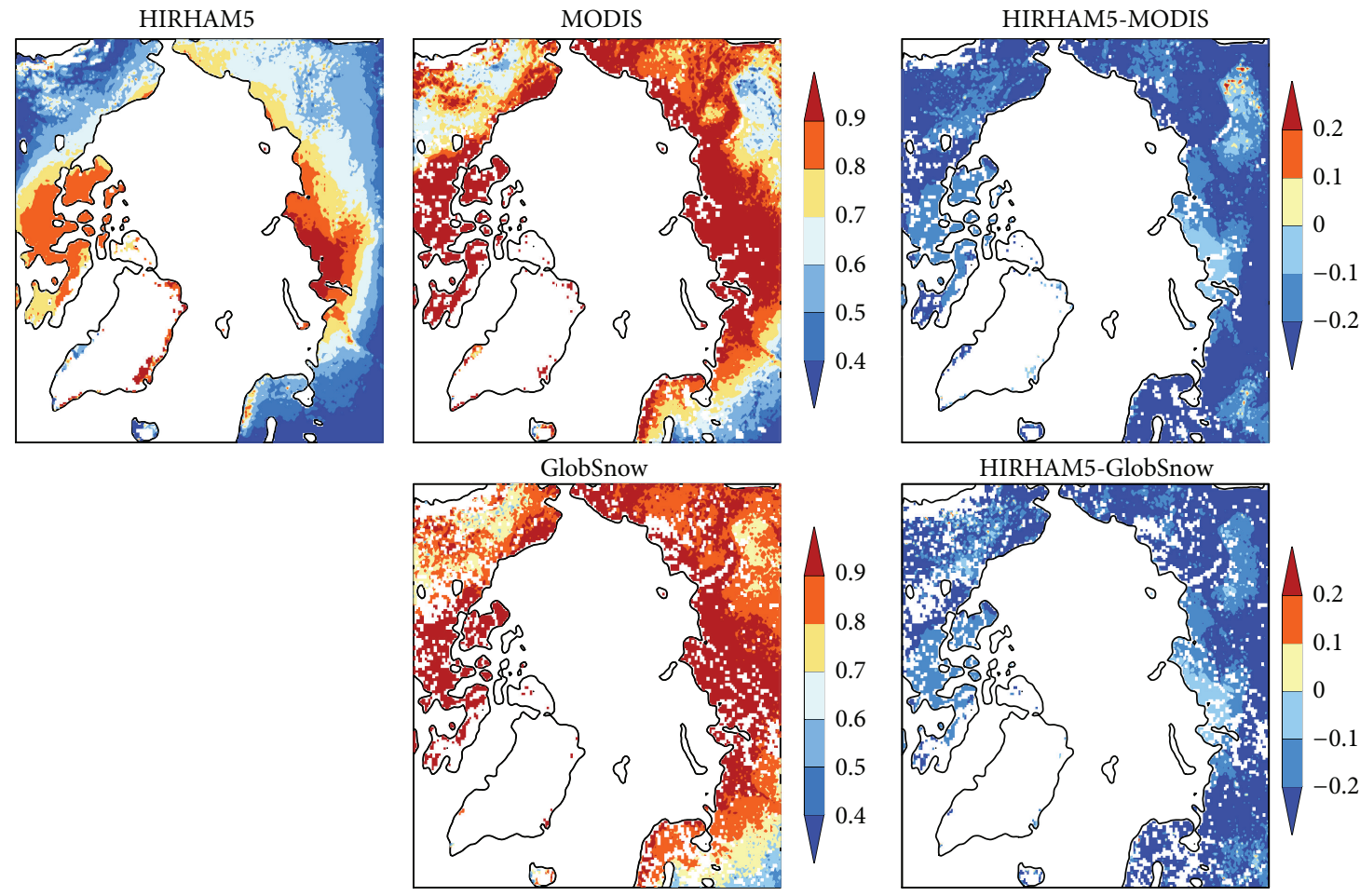

FIGURE 5: Snow cover fraction averaged over 2008-2010 for spring derived from HIRHAM5, MODIS, GlobSnow and their corresponding differences "HIRHAM5 minus MODIS" and "HIRHAM5 minus GlobSnow".
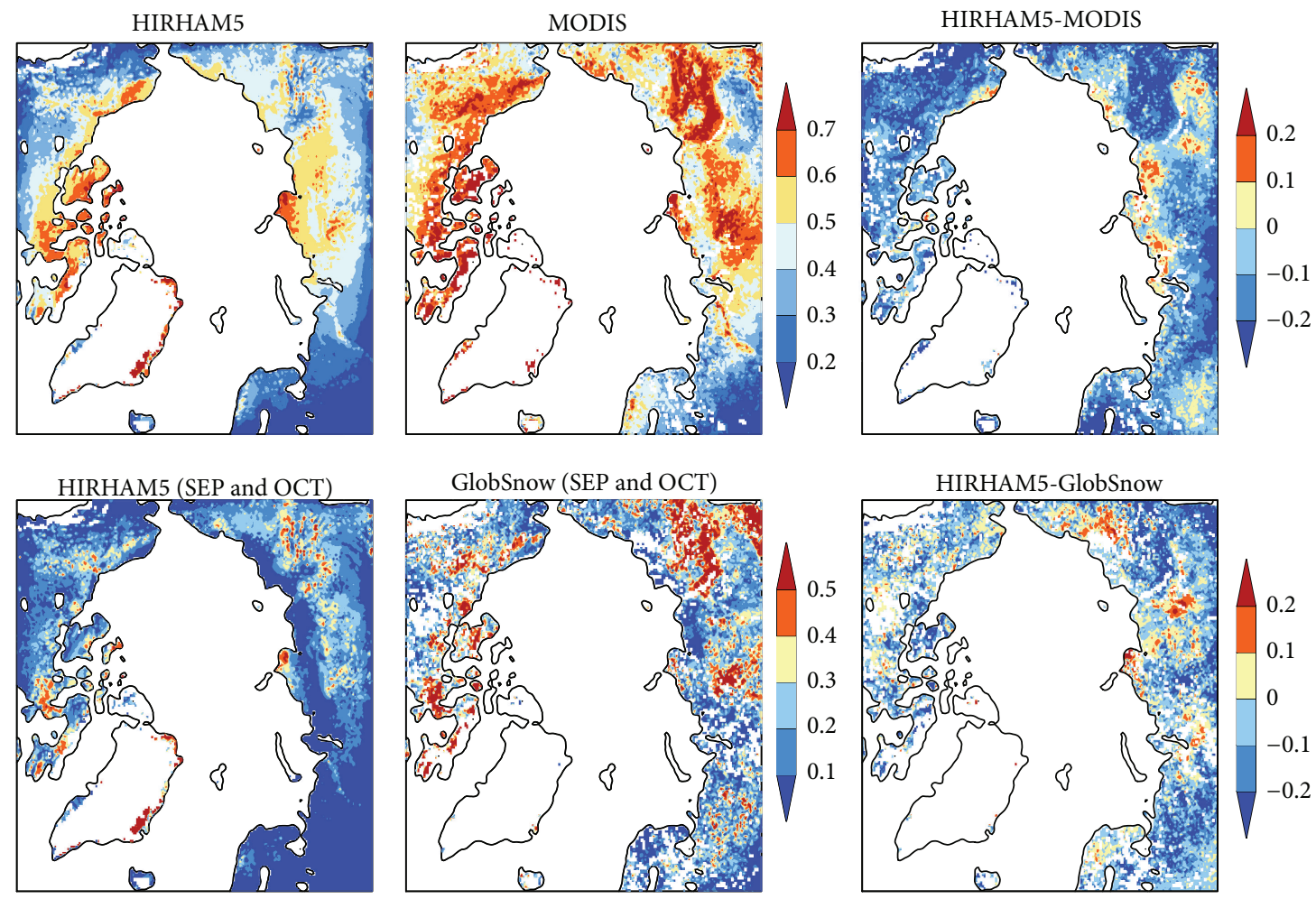

FIGURE 6: Snow cover fraction averaged over 2008-2010 for autumn derived from HIRHAM5, MODIS, GlobSnow and their corresponding differences "HIRHAM5 minus MODIS" and "HIRHAM5 minus GlobSnow". Where the GlobSnow average refers to the September-October period. 

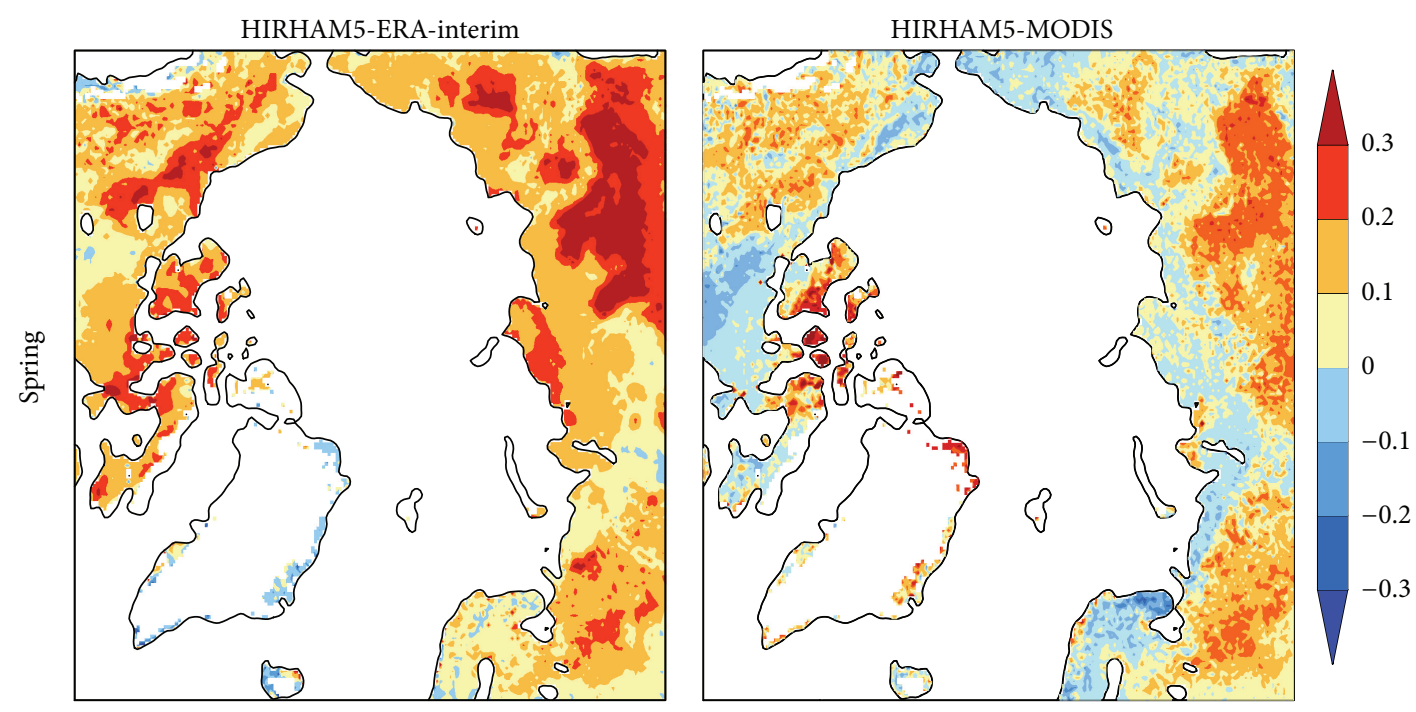

(a)
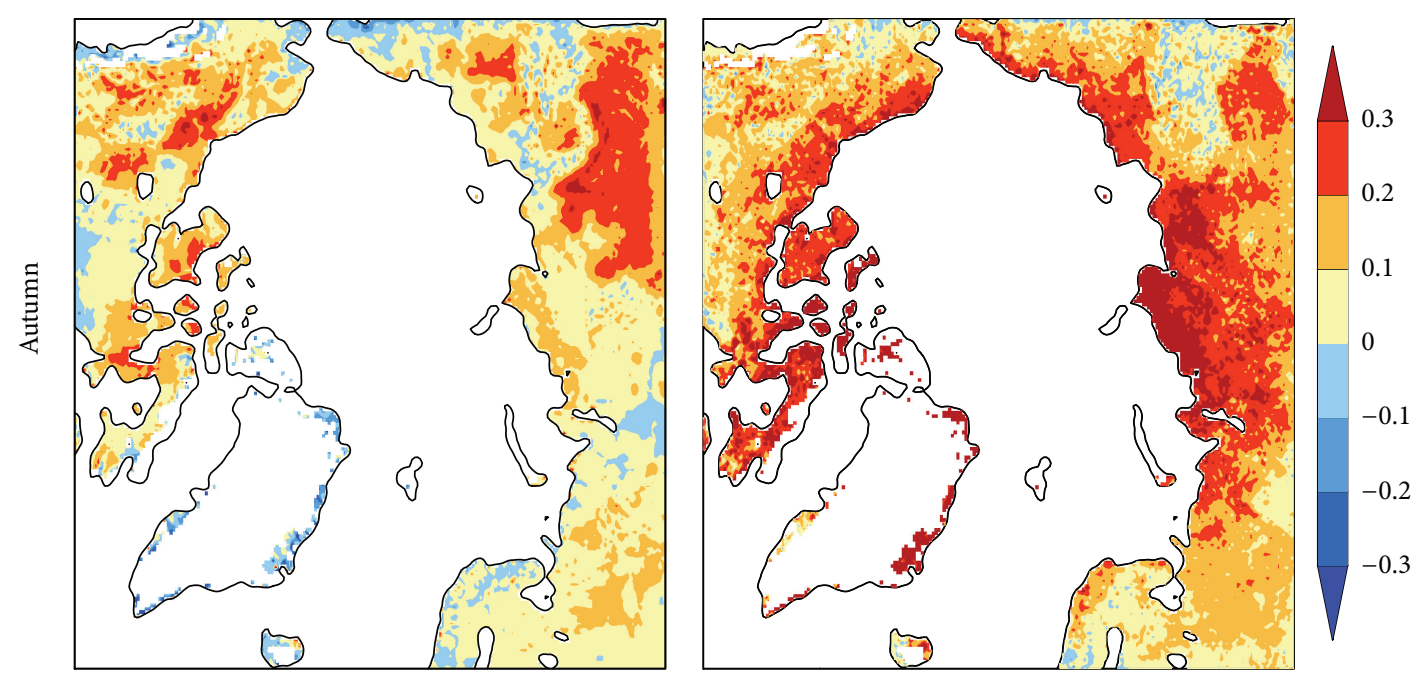

(b)

FIgURE 7: Surface albedo differences "HIRHAM5 minus ERA-Interim" and "HIRHAM5 minus MODIS" for spring (a) and autumn (b), averaged over 2008-2010.

a better simulation of the observed annual cycle of SCF. The results agree well with MODIS and GlobSnow in spring, though a small overestimation in autumn compared with GlobSnow exists. The better CCLM performance could be connected with the separate consideration of deciduous and evergreen forest, which better accounts for their influence on the snow and albedo over forests.

Surface Albedo. Though HIRHAM5 underestimates SWE and SCF, the surface albedo is largely overestimated for the Siberian forest region in spring by more than 0.2 (about $60 \%-$ $70 \%$ ), compared to MODIS and ERA-interim (Figure 10). Over forest regions, the snow-masking effect of fallen leaves and branches that darkens the snow albedo seems to be an important factor to affect the surface albedo simulation for snow covered areas. Note that lack of solar radiation lessens the importance of the snow-masking effect on the albedo during the heavy snow season from October to March [52]. However, the snow-masking effect causes a darker observed albedo. This may play an important role during the transition months of May and September when solar radiation is available. Over nonforest region, the HIRHAM5 albedo shows better agreement with MODIS, especially for the period from April to October. The albedo overestimation in spring is much smaller than over forest. HIRHAM5 reproduces the albedo decrease from April to June with the same rate as MODIS over nonforest. Both for forest and for nonforest areas, the CCLM albedo shows better agreement with MODIS than HIRHAM5, associated with the sophisticated, snowdependent albedo scheme in CCLM (Section 2.6).

During the snow-free months from June to September, the HIRHAM5 and CCLM albedo data agree with the observational data of MODIS and ERA-interim both for forest and for nonforest areas. During the snow free period, the model 


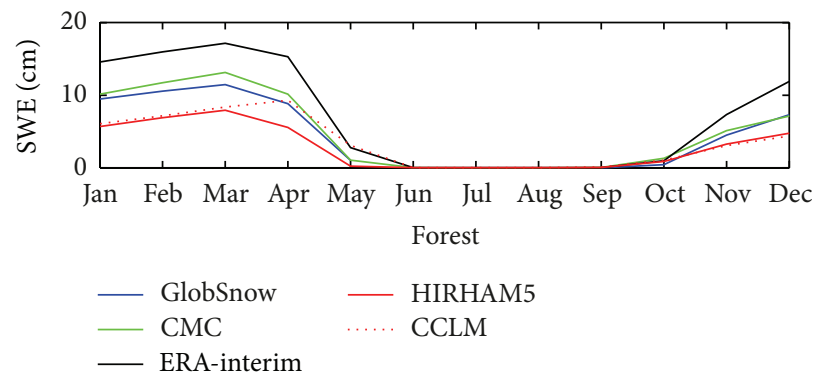

(a)

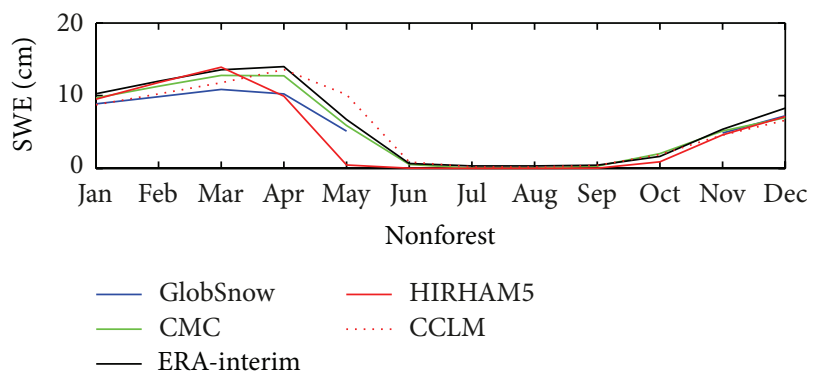

(b)

FIGURE 8: Annual cycle of snow water equivalent (SWE; cm) for Siberian subdomain derived from HIRHAM5, CMC, ERA-interim, GlobSnow and CCLM averaged over 2008 to 2010 for forest (a) and nonforest (b) areas.

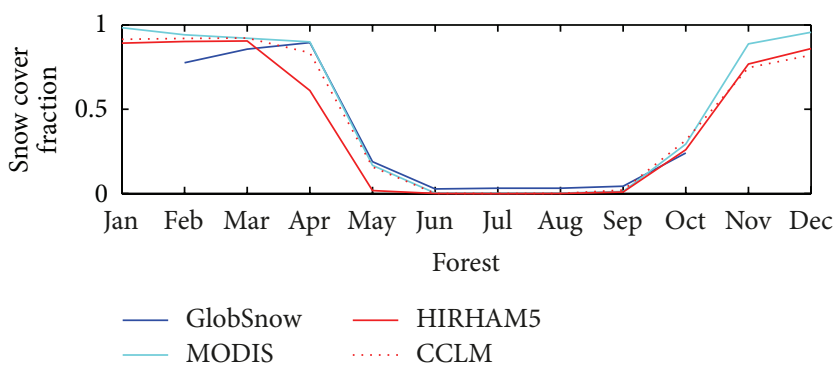

(a)

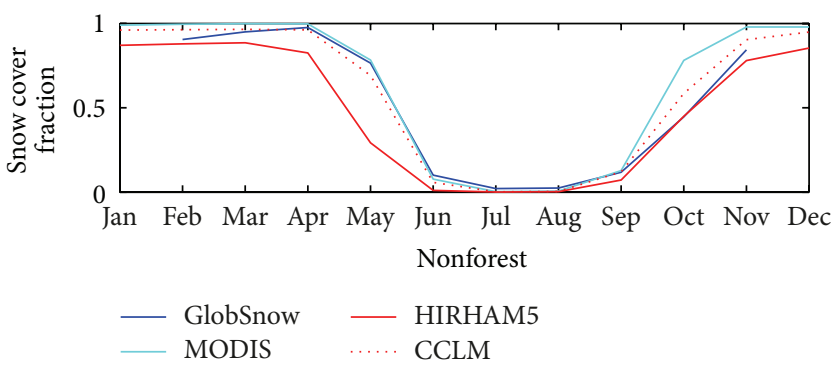

(b)

FiguRE 9: Annual cycle of snow cover fraction for Siberian subdomain derived from HIRHAM5, CCLM, MODIS and GlobSnow averaged over 2008 to 2010 for forest (a) and nonforest (b) areas.

albedo depends only on temperature and forest fraction, and the results show that the applied parameterizations are adequate.

It is worth noting that the ERA-interim albedo over the Siberian forest region shows practically no annual cycle but is more or less fixed to 0.2 . This is due to the snow albedo scheme in the ECMWF forecast model, which limits the deep-snow albedo for boreal forest to 0.2 [38].

4.2. Land Surface Temperature (LST). Figure 11 shows the comparison of HIRHAM5 LST and ERA-Interim LST. The spring and autumn LST spatial bias patterns (Figure 11) 


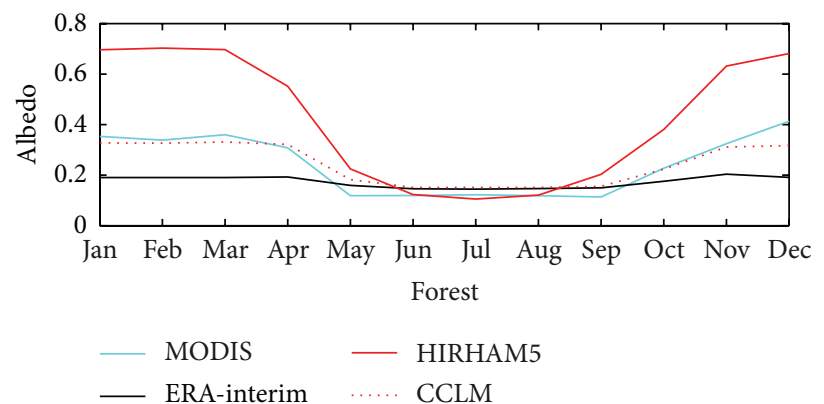

(a)

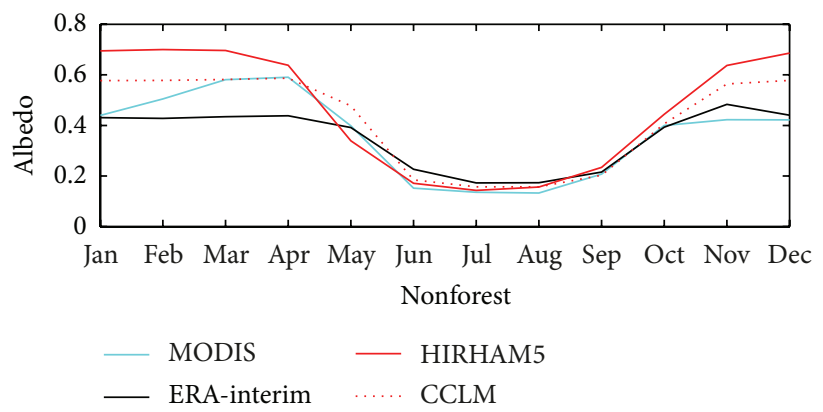

(b)

FIGURE 10: Annual cycle of surface albedo for Siberian subdomain derived from HIRHAM5, CCLM, ERA-interim and MODIS averaged over 2008 to 2010 for forest (a) and nonforest (b) areas.

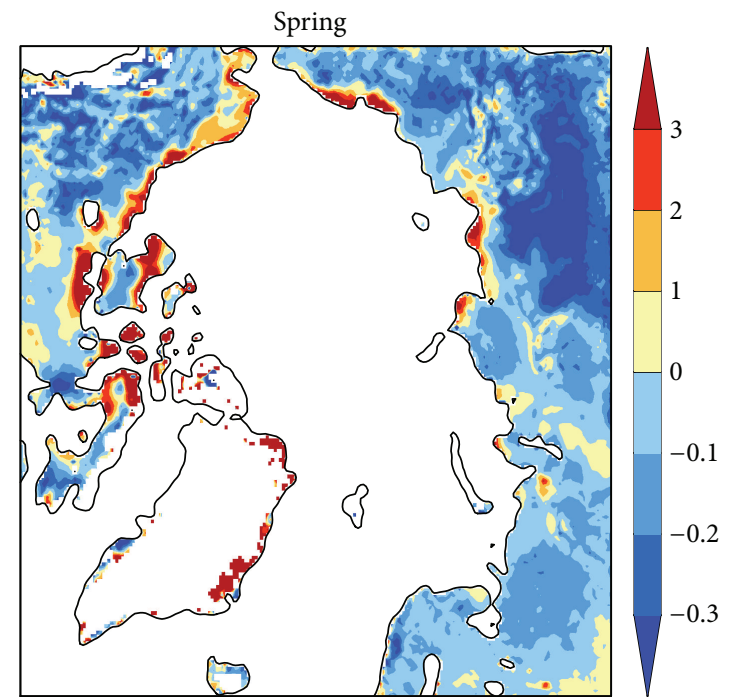

(a)

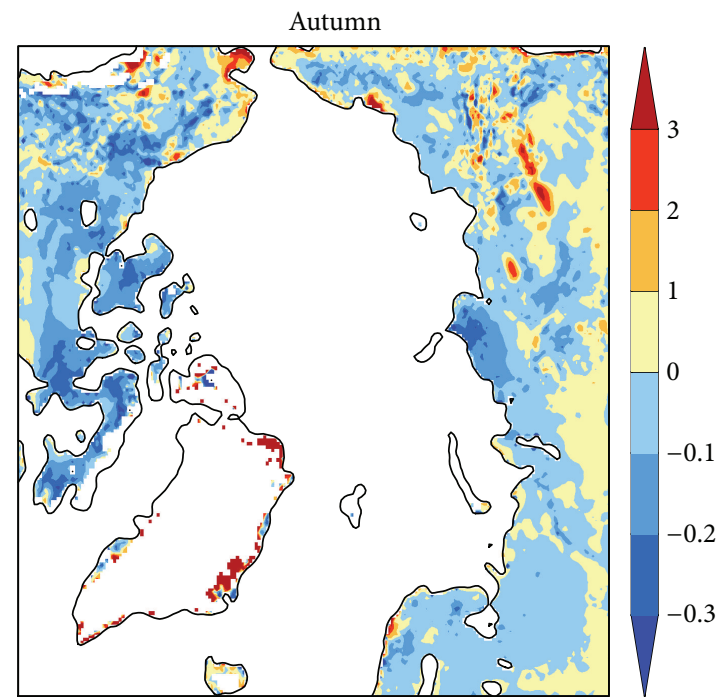

(b)

FIGURE 11: Land surface temperature difference “HIRHAM5 minus ERA-Interim” (K) averaged over 2008-2010 for spring (a) and autumn (b).

resemble the albedo bias patterns (Figure 7). In spring, HIRHAM5 is up to $4 \mathrm{~K}$ colder over the Siberian forest region. The autumn LST bias ranges between $-3 \mathrm{~K}$ and $3 \mathrm{~K}$ and is obviously not related to the vegetation cover.

By comparing the simulated LST annual cycle with ERAinterim over the Siberian region (Figure 12), we recognize that both models simulate the LST annual cycle well and the deviations from March to October are smaller than in the other months. In winter, the models tend to be warmer than ERA-interim, particularly CCLM. The LST agreement in spring and autumn is good, except for HIRHAM5 over forest areas in March and April. Here, the better SCF and albedo simulation in CCLM affect the better CCLM LST results. Though the HIRHAM5 forest albedo is higher for most of the months, the temperature bias is only limited to March and April, because the snow albedo affection to LST is obvious 


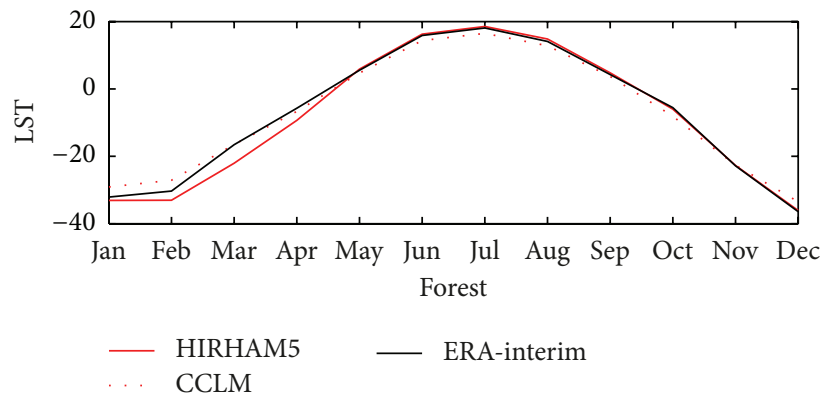

(a)

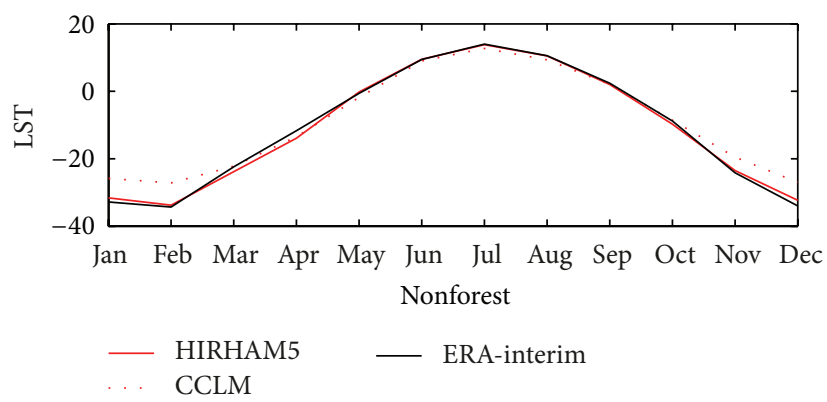

(b)

FIGURE 12: Annual cycle of land surface temperature (LST; $\left.{ }^{\circ} \mathrm{C}\right)$ for Siberian subdomain derived from HIRHAM5, CCLM and ERA-interim for forest (a) and nonforest (b) areas averaged over 2008 to 2010.

when the solar radiation becomes stronger (e.g., March and April), while the solar radiation (and albedo effect) in winter is quite small. And this effect will decrease with progressive snow melting.

At the beginning, we aimed to compare the simulated LST with the MODIS-derived LST. However, the following limitations have to be considered such that we decided not to do so: LST MODIS observational data are only for clear-sky cases. Thus, it is difficult to compare satellite data with modeled results for whole time period. Even if the comparison would be focused on clear-sky LST, due to different temporal and spatial samplings between satellite and model, such a comparison is not firm. Also because our HIRHAM5 simulation is relatively short, if one compares the two datasets, the sampling of clear-sky versus cloudy-sky data needs to be considered carefully in order to keep the temporal uniformity of the comparison. Therefore, we cannot directly compare LST-derived by MODIS and modeled LST. With the state of observational data, comparison between model and satellite data has to be limited to LST-driving parameters like SCF and SWE. Therefore, the modeled LST is only compared with ERA-interim data due to limitations of satellite-derived LST.

\section{Summary and Conclusion}

In this study, HIRHAM5 modeled Arctic land snow cover; albedo and LST are evaluated in spring and autumn using various satellite and reanalysis data. In addition, the HIRHAM data is compared with CCLM as second RCM.
HIRHAM5 can generally capture the main characteristics of the spatial patterns and the annual evolution of SWE, SCF, albedo, and LST, although significant biases are detected.

It has been shown that the simulation of snow cover characteristics (SWE, SCF, and albedo) over forest areas is difficult for the model, particularly in spring during the snow melt. The albedo and temperature bias in spring for Siberian deciduous tree forest is obvious in HIRHAM5. This could be caused by neglecting the snow-masking effect of fallen leaves and branches for deciduous tree forest in the SCF parameterization, since SCF is a key variable to control the albedo simulation in spring. The effect of improved SCF and albedo simulations on the improved LST is shown by the CCLM results. Less snow cover leads to lower albedo, which causes more solar radiation absorption and this further accelerates snow melting. This process is a positive feedback and small biases can be amplified and then reflected in the LST bias. The implication of this result is that the simulated spring and autumn LST can be mainly improved by improving the regional snow cover and thus the surface albedo.

Our finding of the unsatisfactory nature of the Siberian forest albedo parameterization is in agreement with Roesch and Roeckner [51], who pointed out this weakness for the applied ECHAM5 parameterization. Thus we suggest for the albedo parameterization a separate consideration of forest types (e.g., such as in CCLM) and the implementation of the effect of fallen leaves and branches on snow. The simulated nonforest SWE, SCF, and albedo are in reasonable agreement with the observations. The applied temperature and forest fraction dependent albedo parameterization works well. 
There are also limitations in the use of the selected datasets. Differences between the different data sets have been presented. For instance, SWE derived from CMC and Globsnow and autumn SCF derived from MODIS and GlobSnow differ considerably. For such cases it is difficult to evaluate the model simulations and the comparisons need to take all available observational data sets into account. In addition, optical satellite retrievals are difficult for dense cloud cover and for cloud cover over snow and ice surfaces, which will cause contamination of data [52].

The evaluation of our study is restricted to only 3 years: a time span where all data products overlap. However, this short period is sufficient when looking at mean values and the evaluation results do not differ when more years are included (e.g., 10 years is tested). Nevertheless, for further climate statistics the data of long-term simulations should be included in future work.

\section{Conflict of Interests}

The authors declare that there is no conflict of interests regarding the publication of this paper.

\section{Acknowledgments}

This work has been funded by the Helmholtz Climate Initiative REKLIM (Regional Climate Change), a joint research project of the Helmholtz Association of German research centers (HGF). The authors thank Ines Hebestadt's support in the HIRHAM5 simulation.

\section{References}

[1] M. C. Serreze and R. G. Barry, "Processes and impacts of Arctic amplification: a research synthesis," Global and Planetary Change, vol. 77, no. 1-2, pp. 85-96, 2011.

[2] M. O. Jeffries, J. A. Richter-Menge, and J. E. Overland, Eds., Arctic Report Card 2013, 2013, http://www.arctic.noaa.gov/reportcard/.

[3] T. Zhang, "Influence of the seasonal snow cover on the ground thermal regime: an overview," Reviews of Geophysics, vol. 43, no. 4, Article ID RG4002, 2005.

[4] D. M. Lawrence and A. G. Slater, "The contribution of snow condition trends to future ground climate," Climate Dynamics, vol. 34, no. 7, pp. 969-981, 2010.

[5] S. Aoki, M. Yoritaka, and A. Masuyama, "Multidecadal warming of subsurface temperature in the Indian sector of the Southern Ocean," Journal of Geophysical Research C: Oceans, vol. 108, no. C4, 2003.

[6] A. Hall, "The role of surface albedo feedback in climate," Journal of Climate, vol. 17, pp. 1550-1568, 2004.

[7] M. Takala, J. Pulliainen, S. J. Metsämäki, and J. T. Koskinen, "Detection of snowmelt using spaceborne microwave radiometer data in Eurasia from 1979 to 2007," IEEE Transactions on Geoscience and Remote Sensing, vol. 47, no. 9, pp. 2996-3007, 2009.

[8] W. F. Vincent, T. V. Callaghan, D. Dahl-Jensen et al., "Ecological implications of changes in the arctic cryosphere," AMBIO, vol. 40, no. 1, pp. 87-99, 2011.
[9] I. M. Shkolnik, V. P. Meleshko, and V. M. Kattsov, "The MGO climate model for Siberia," Russian Meteorology and Hydrology, vol. 32, no. 6, pp. 351-359, 2007.

[10] K. Klehmet, B. Geyer, and B. Rockel, "A regional climate model hindcast for Siberia: analysis of snow water equivalent," Cryosphere, vol. 7, no. 4, pp. 1017-1034, 2013.

[11] K. Wang, J. Liu, X. Zhou et al., "Validation of MODIS global land surface albedo product using ground measurements in a semidesert region on the Tibetan Plateau," Journal of Geophysical Research D: Atmospheres, vol. 109, no. 5, pp. D05107-D05109, 2004.

[12] K. Wang, S. Liang, C. L. Schaaf, and A. H. Strahler, "Evaluation of moderate resolution imaging spectroradiometer land surface visible and shortwave albedo products at FLUXNET sites," Journal of Geophysical Research D, vol. 115, no. 17, Article ID D17107, 2010.

[13] A. Cescatti, B. Marcolla, S. K. Santhana Vannan et al., "Intercomparison of MODIS albedo retrievals and in situ measurements across the global FLUXNET network," Remote Sensing of Environment, vol. 121, pp. 323-334, 2012.

[14] D. K. Hall, G. A. Riggs, and V. V. Salomonson, Updated Monthly. "MODIS/TERRA Snow Cover Monthly L3 Global 0.05Deg CMG V005," Boulder, CO, National Snow and Ice Data Center. Digital Media, Distributed in netCDF Format by the Integrated Climate Data Center (ICDC), University of Hamburg, Hamburg, Germany, 2006, http://icdc.zmaw.de/.

[15] V. V. Salomonson and I. Appel, "Estimating fractional snow cover from MODIS using the normalized difference snow index," Remote Sensing of Environment, vol. 89, no. 3, pp. 351360, 2004.

[16] G. A. Riggs, D. K. Hall, and V. V. Salomonson, "MODIS Snow Products User Guide to Collection 5," 2006.

[17] D. K. Hall and G. A. Riggs, "Accuracy assessment of the MODIS snow products," Hydrological Processes, vol. 21, no. 12, pp. 15341547, 2007.

[18] K. R. Arsenault, P. R. Houser, G. J. M. de Lannoy, and P. A. Dirmeyer, "Impacts of snow cover fraction data assimilation on modeled energy and moisture budgets," Journal of Geophysical Research, vol. 118, no. 14, pp. 7489-7504, 2013.

[19] A. Simic, R. Fernandes, R. Brown, P. Romanov, and W. Park, "Validation of VEGETATION, MODIS, and GOES + SSM/I snow-cover products over Canada based on surface snow depth observations," Hydrological Processes, vol. 18, no. 6, pp. 10891104, 2004.

[20] R. D. Brown and B. Brasnett, "Canadian Meteorological Centre (CMC) Daily Snow Depth Analysis Data," NASA DAAC at the National Snow and Ice Data Center, Boulder, Colo, USA, 2010.

[21] B. Brasnett, "A global analysis of snow depth for numerical weather prediction," Journal of Applied Meteorology, vol. 38, no. 6, pp. 726-740, 1999.

[22] R. D. Brown and P. W. Mote, "The response of Northern Hemisphere snow cover to a changing climate," Journal of Climate, vol. 22, no. 8, pp. 2124-2145, 2009.

[23] M. Sturm, J. Holmgren, and G. E. Liston, "A seasonal snow cover classification system for local to global applications," Journal of Climate, vol. 8, no. 5, pp. 1261-1283, 1995.

[24] K. Luojus, J. Pulliainen, and GlobSnow Consortiuum, "Global Snow Monitoring for Climate Research: Snow Water Equivalent," Finnish Meteorological Institute, Helsinki, Finland, 2010, http://www.globsnow.info/index.php?page=Home/. 
[25] K. Luojus, J. Pulliainen, M. Takala et al., "Algorithm Theoretical Basis Document SWE algorithm," 2013, http://www.globsnow .info/docs/GS2_SWE_ATBD.pdf.

[26] S. Metsamaki, M. Salminen, J. Pulliainen et al., "Algorithm Theoretical Basis Document SE algorithm," 2013, http://www.globsnow.info/docs/GS2_SE_ATBD.pdf.

[27] S. J. Metsämäki, S. T. Anttila, H. J. Markus, and J. M. Vepsäläinen, "A feasible method for fractional snow cover mapping in boreal zone based on a reflectance model," Remote Sensing of Environment, vol. 95, no. 1, pp. 77-95, 2005.

[28] M. Salminen, J. Pulliainen, S. Metsämäki, A. Kontu, and H. Suokanerva, "The behaviour of snow and snow-free surface reflectance in boreal forests: implications to the performance of snow covered area monitoring," Remote Sensing of Environment, vol. 113, no. 5, pp. 907-918, 2009.

[29] J. Pulliainen, "Mapping of snow water equivalent and snow depth in boreal and sub-arctic zones by assimilating spaceborne microwave radiometer data and ground-based observations," Remote Sensing of Environment, vol. 101, no. 2, pp. 257269, 2006.

[30] M. Takala, K. Luojus, J. Pulliainen et al., "Estimating northern hemisphere snow water equivalent for climate research through assimilation of space-borne radiometer data and ground-based measurements," Remote Sensing of Environment, vol. 115, no. 12, pp. 3517-3529, 2011.

[31] J. L. Foster, C. Sun, J. P. Walker et al., "Quantifying the uncertainty in passive microwave snow water equivalent observations," Remote Sensing of Environment, vol. 94, no. 2, pp. 187203, 2005.

[32] D. P. Dee, S. M. Uppala, A. J. Simmons et al., "The ERA-Interim reanalysis: configuration and performance of the data assimilation system," Quarterly Journal of the Royal Meteorological Society, vol. 137, no. 656, pp. 553-597, 2011.

[33] D. P. Dee and S. Uppala, "Variational bias correction of satellite radiance data in the ERA-Interim reanalysis," Quarterly Journal of the Royal Meteorological Society, vol. 135, no. 644, pp. 18301841, 2009.

[34] H. Douville, J. F. Royer, and J. F. Mahfouf, "A new snow parameterization for the Meteo-France climate model. Part I: validation in stand-alone experiments," Climate Dynamics, vol. 12, no. 1, pp. 21-35, 1995.

[35] M. Drusch, D. Vasiljevic, and P. Viterbo, "ECMWF's global snow analysis: assessment and revision based on satellite observations," Journal of Applied Meteorology and Climatology, vol. 43, no. 9, pp. 1282-1294, 2004.

[36] E. Dutra, G. Balsamo, P. Viterbo et al., "An improved snow scheme for the ECMWF land surface model: description and offline validation," Journal of Hydrometeorology, vol. 11, no. 4, pp. 899-916, 2010.

[37] D. L. Verseghy, "CLASS-a Canadian land surface scheme for GCMs. I. Soil model," International Journal of Climatology, vol. 11, no. 2, pp. 111-133, 1991.

[38] P. Viterbo and A. K. Betts, "Impact of the ECMWF reanalysis soil water on forecasts of the July 1993 Mississippi flood," Journal of Geophysical Research D: Atmospheres, vol. 104, no. 16, pp. 19361-19366, 1999.

[39] P. Undén, L. Rontu, P. Lynch et al., "The HIRLAM-5 scientic documentation. HIRLAM-5 project," SMHI, Norrkoping, Sweden, 2002.

[40] E. Roeckner, G. Bäuml, L. Bonaventura et al., The Atmospheric General Circulation Model ECHAM5. Part II: Simulated
Climatology and Comparison with Observations, Max-PlanckInstitute for Meteorology, Hamburg, Germany, 2003.

[41] A. Rinke, H. Matthes, J. H. Christensen, P. Kuhry, V. E. Romanovsky, and K. Dethloff, "Arctic RCM simulations of temperature and precipitation derived indices relevant to future frozen ground conditions," Global and Planetary Change, vol. 80-81, pp. 136-148, 2012.

[42] H. Matthes, A. Rinke, P. A. Miller, P. Kuhry, K. Dethloff, and A. Wolf, "Sensitivity of high-resolution Arctic regional climate model projections to different implementations of land surface processes," Climatic Change, vol. 111, no. 2, pp. 197-214, 2012.

[43] S. Hagemann, "An improved land surface parameter dataset for global and regional climate models," Tech. Rep. 336, MaxPlanck-Institute for Meteorology, Hamburg, Germany, 2002.

[44] A. Roesch, M. Wild, H. Gilgen, and A. Ohmura, "A new snow cover fraction parameterization for the ECHAM4 GCM," Climate Dynamics, vol. 17, no. 12, pp. 933-946, 2001.

[45] B. Rockel, A. Will, and A. Hense, "Special issue Regional climate modelling with COSMO-CLM (CCLM)," Meteorological Journal, vol. 17, pp. 347-348, 2008.

[46] G. Doms, J. Forstner, E. Heise et al., "A description of the nonhydrostatic regional COSMO model. Part II: physical parameterization," Tech. Rep., Deutscher Wetterdienst, 2011, http://www.cosmo-model.org/content/model/documentation/core/cosmoPhysParamtr.pdf.

[47] W. H. Theakstone, "Long-term variations of the seasonal snow cover in Nordland, Norway: the influence of the North Atlantic Oscillation," Annals of Glaciology, vol. 54, no. 62, pp. 25-34(10), 2013.

[48] J. Tong, S. J. Dery, and P. L. Jackson, "Interrelationships between MODIS/Terra remotely sensed snow cover and the hydrometeorology of the Quesnel River Basin, British Columbia, Canada," Hydrology and Earth System Sciences, vol. 13, no. 8, pp. 14391452, 2009.

[49] Y. Gao, H. Xie, and T. Yao, "Developing snow cover parameters maps from MODIS, AMSR-E, and blended snow products," Photogrammetric Engineering and Remote Sensing, vol. 77, no. 4, pp. 351-361, 2011.

[50] S. Anttila, S. Metsämäki, J. Pulliainen, and K. Luojus, "From EO data to snow covered area (SCA) end products using automated processing system," in Proceedings of the IEEE International Geoscience and Remote Sensing Symposium (IGARSS '05), pp. 1947-1950, Seoul, Republic of Korea, July 2005.

[51] A. Roesch and E. Roeckner, "Assessment of snow cover and surface albedo in the ECHAM5 general circulation model," Journal of Climate, vol. 19, no. 16, pp. 3828-3843, 2006.

[52] Ø. Torbjørn, S. Thomas, and W. Sebastian, Quality Assessment of MODIS Land Surface Temperatures over an Arctic Ice Cap, vol. 15, EGU, 2013. 

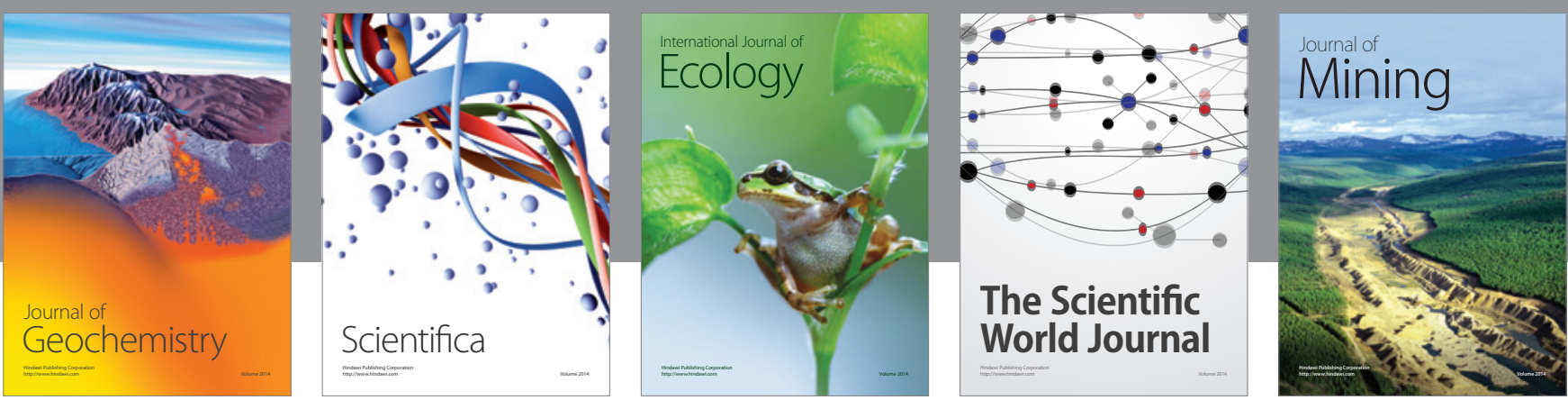

The Scientific World Journal
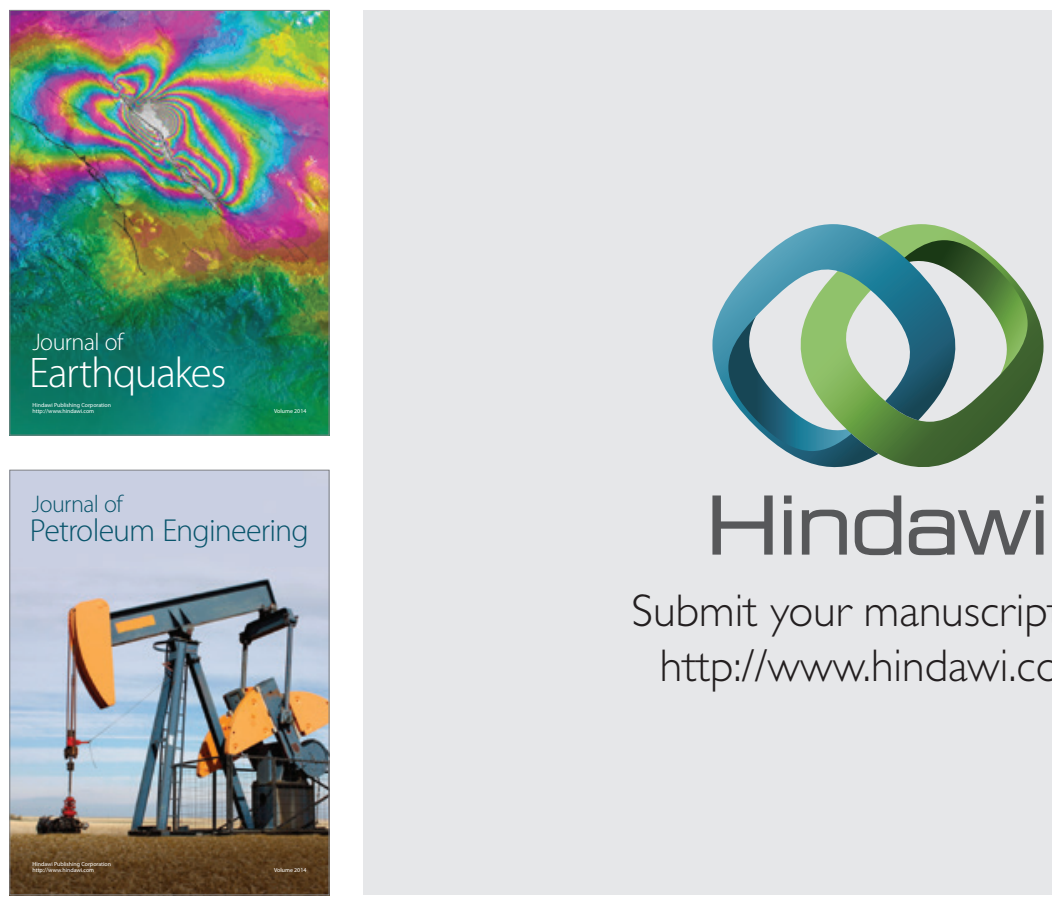

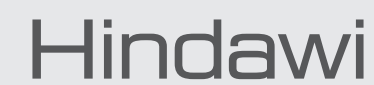

Submit your manuscripts at

http://www.hindawi.com
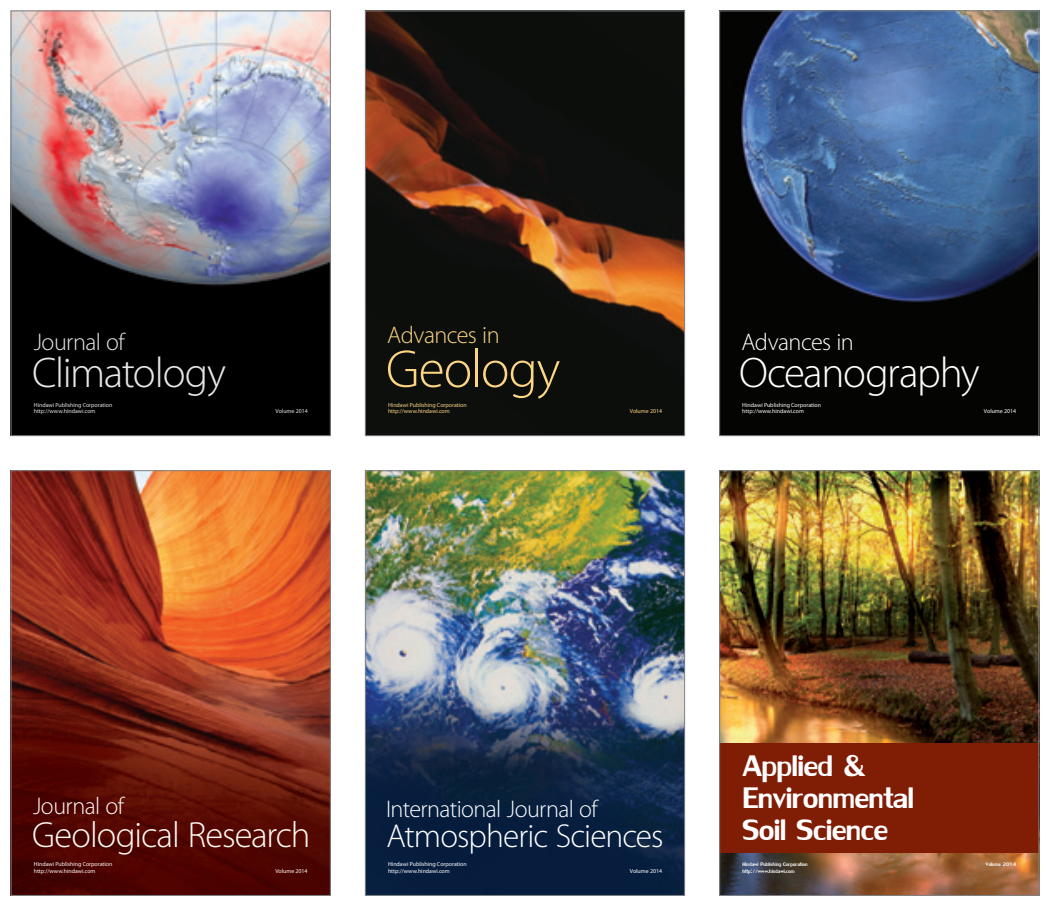
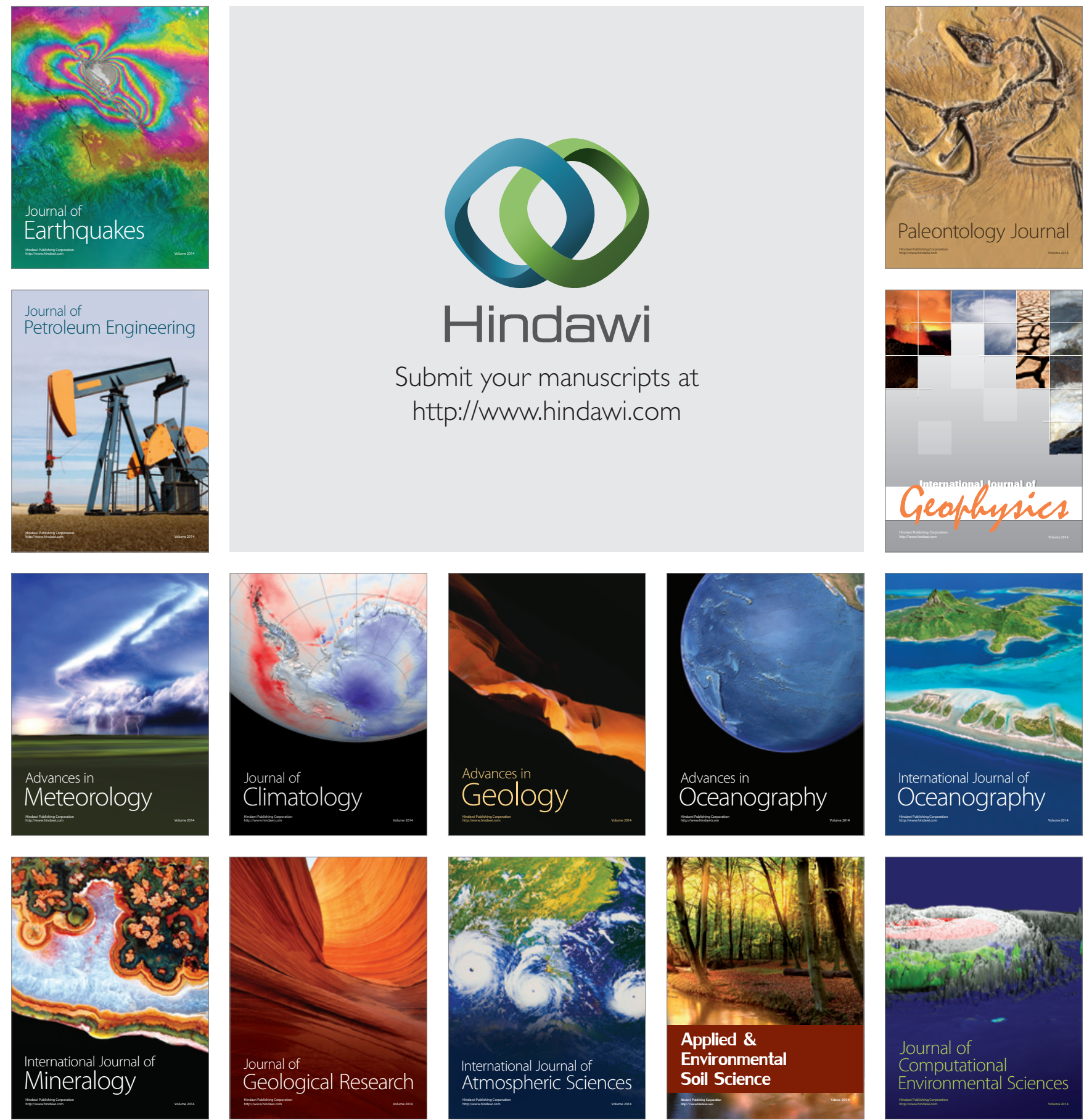